\title{
Phytochemical investigation of Phoenix canariensis Hort. ex Chabaud leaves and pollen grains
}

\author{
Mohamed S. Hifnawy, Amr M. K. Mahrous, Rehab M. S. Ashour \\ Pharmacognosy Department, Faculty of pharmacy, Cairo University, Kasr El-Aini 11562, Egypt.
}

\begin{tabular}{|c|c|}
\hline ARTICLE INFO & ABSTRACT \\
\hline Article history: & \multirow{10}{*}{$\begin{array}{l}\text { Phoenix canariensis is a commonly grown, yet understudied, palm plant. The phytochemical screening of leaves } \\
\text { and pollens revealed the presence of flavonoids, saponins, tannins, sterols and/or triterpenes. Quantitative } \\
\text { estimation of constituents, revealed that the total polyphenolics were higher in the leaves (69.9) than in pollens } \\
(29.98) \text { expressed in } \mathrm{mg} \text { gallic acid equivalent/g d.wt, the total flavonoids calculated as rutin equivalent were } \\
(23.86 \mathrm{mg} / \mathrm{g} \text { ) in leaves and }(17.20 \mathrm{mg} / \mathrm{g} \text { ) in pollens, the total tannins content were } 55.18 \text { and } 3.31 \mathrm{mg} \text { tannic acid } \\
\text { equivalent/g fresh wt, while the total steroids content were } 2.6 \text { and } 12.4 \mathrm{mg} \beta \text {-sitosterol equivalent/g d.wt, in } \\
\text { leaves and pollens, respectively. Eighteen phenolic compounds and ten flavonoids were identified by HPLC. } \\
\text { GLC analysis of lipids, revealed the identification of phytosterols }(4.93 \text { and } 28.90 \%) \text {, saturated ( } 35.35 \text { and } \\
40.56 \%) \text { and unsaturated ( } 62.42 \text { and } 59.01 \%) \text { fatty acids in leaves and pollens, respectively. Proximate analysis } \\
\text { revealed a total moisture content of }(6.4 \text { and } 7.7 \%) \text {, crude fiber }(32.22 \text { and } 39.50 \%) \text {, total ash }(12.1 \text { and } 8.1 \%) \\
\text { and acid insoluble ash ( } 4.7 \text { and } 7.6 \%) \text { for leaves and pollens, respectively. Moreover, spathe headspace volatile } \\
\text { analysis combined with GC-MS revealed the presence of fifty-two compounds constituting } 72.84 \% \text { of the total } \\
\text { oil composition where } \alpha \text { - copaene predominates }(18.72 \%) \text {. }\end{array}$} \\
\hline Received on: 08/09/2016 & \\
\hline Revised on: 09/10/2016 & \\
\hline Accepted on: 22/11/2016 & \\
\hline Available online: $28 / 12 / 2016$ & \\
\hline Key words: & \\
\hline Phoenix canariensis, Lipids, & \\
\hline Headspace volatiles, & \\
\hline Flavonoids, Phenolics, & \\
\hline Steroids. & \\
\hline
\end{tabular}

\section{INTRODUCTION}

Palms are among the best known and extensively cultivated plant families and they are of great economic importance. They all belong to family Arecaceae (Johnson, 1998). Palms have been cultivated in the Middle East and North Africa for at least 5000 years (Zohary and Hopf, 2000). The genus Phoenix (Family Arecaceae) comprises about 19 species, distributed in tropical and subtropical areas southern Asia and Africa (Adawy et al., 2002, Mohtasheem et al., 2005) Phoenix canariensis, the Canary date palm, is native to the Canary Islands. It is widely planted as ornamental in the US and the Mediterranean area (Krueger, 2001). It can be identified by its single, upright, thick trunk topped with a crown of leaves in 2.5 to 4.5 meters long. The stalks of inconspicuous flowers are

\footnotetext{
* Corresponding Author

Rehab M.S. Ashour, Pharmacognosy Department, Faculty of pharmacy, Cairo University, Kasr El-Aini 11562, Egypt.

Email: rehab.ashour@pharma.cu.edu.eg
}

replaced with clusters of one inch diameter, orange yellow, datelike, ornamental fruits, which ripen in summer (Gilman and Watson, 2006). The inflorescence of most palm trees in its early stage of growth is enclosed in hard covering envelop known as spathe, which splits open as the flowers reach maturation (Zaid and Arias-Jimenez, 2002).

Earlier studies have reported the great medicinal use of different parts of genus Phoenix, as antioxidant (Kchaou et al., 2013), anti-inflammatory, antitumor (Rahmani et al., 2014), antibacterial (Al-Zoreky and Al-Taher, 2015), antifungal, neuroprotective (Pujari et al., 2014) and hepatoprotective agents (Singab et al, 2015). The fruits of Phoenix dactylifera Linn. have been traditionally used to treat various disorders including diabetes and hypertension.

In Egypt, pollens were believed to enhance fertility and to be an aphrodisiac. Several constituents have been identified and isolated from the genus including lipids, phenolic acids, flavonoids, procyanidins, saponins, triterpenes, sterols and carbohydrates (Elgindi et al., 2015). 
To the best of our knowledge, no published data was found concerning the pollen grains and spathe of the plant while only few reports were found concerning the isolation of flavonoids, phenolic acid and steroidal saponin from the leaves (Garcia et al., 1981; Asami et al., 1991) and isolation of an alkaloid from the seeds as well as seed oil chemical composition (Hammami et al., 2010; Nehdi et al., 2011). This study includes the determination of pharmacopoeial constants, phytochemical screening, spectroscopic analysis of different classes, HPLC analysis of polyphenolics and GLC analysis of lipids for leaves and pollen grains of Phoenix canariensis in addition to its spathe volatile analysis.

\section{MATERIAL AND METHODS}

\section{Plant material}

Phoenix canariensis hort. ex Chabaud leaves and pollens were collected over the years 2013-2015 from El-Orman Botanical Garden, Egypt. The plant was identified by Dr. Mohamed el Gebaly (Taxonomist) and Mrs. Therese Labib, consultant of plant taxonomy at the Ministry of Agriculture. Voucher specimens numbered (5.10.2015), were deposited at the Herbarium of the Pharmacognosy Department, Faculty of Pharmacy, Cairo University. Spathe used for volatiles analysis was collected in summer.

\section{Phytochemical screening}

The powdered air dried leaves and pollen grains were tested for the presence of steam volatile substances (Wagner et al., 1983), flavonoids (Geissman, 1962, Peach and Tracey, 1955), crystalline sublimate (Claus and Tyler, 1967), tannins (Evans, 2002), cardiac glycosides (Fieser and Fieser,1959), sterols and /or triterpenes, alkaloids and / or nitrogenous bases, anthraquinones, saponins, carbohydrates and/or glycosides (Tiwari et al., 2011).

\section{Proximate analysis}

Moisture, crude fiber, total ash and acid insoluble ash were determined (AOAC, 2000). Each value was an average of 3 determinations.

\section{Quantification of different chemical classes of plant constituents}

Spectrophotometric determination of total polyphenolic content

The total polyphenolic content was performed using Folin-Ciocalteu reagent. A calibration curve $\left(\mathrm{R}^{2}=0.9987\right)$ was prepared using gallic acid standard (Sigma Co., St. Louis, MO, USA) at concentrations of $50 \mu \mathrm{g}$ to $0.9 \mathrm{mg} / \mathrm{ml}$. Total content of phenolic compounds was calculated as gallic acid equivalents (GAE) (Singleton et al.,1999). For each concentration, three replicates were carried out.

\section{Spectrophotometric determination of flavonoid content}

Spectrophotometric determination of total flavonoid content was based on measuring the intensity of the yellow colour developed when flavonoids were complexed with aluminum chloride reagent at $420 \mathrm{~nm}$ using UV spectrophotometer expressed as rutin equivalent. A standard calibration curve $\left(R^{2}=0.9984\right)$ was prepared using different aliquots of standard rutin (Sigma Co., St. Louis, MO, USA) equivalent to $20-180 \mu \mathrm{g} / \mathrm{ml}$ (Geissman, 1962). Three replicates were carried out, for each concentration.

\section{Spectrophotometric determination of total tannin content}

Tannin content was estimated by Folin- Denis reagent using tannic acid as standard (Sigma Co., St. Louis, MO, USA) (Earp et al., 1981). A standard calibration curve $\left(\mathrm{R}^{2}=0.9998\right)$ was prepared using tannic acid concentrations ranging from 0 $100 \mu \mathrm{g} / \mathrm{ml}$. The values were expressed in micrograms $(\mu \mathrm{g})$ of tannic acid equivalents (TAE) per gram fresh weight. Three replicates were carried out, for each concentration.

\section{Spectrophotometric determination of total steroidal content}

The determination of total steroidal content of leaves and pollen grains was based on measuring the intensity of the green colour developed when steroidal compound complexes with Libermann-Burchard's reagent using $\beta$-sitosterol as a standard. A standard calibration curve $\left(\mathrm{R}^{2}=0.9981\right)$ was prepared using different aliquots of $\beta$-sitosterol solution (E-Merk, Darmstadt, Germany) equivalent to 0.1 to $0.5 \mathrm{mg} / \mathrm{ml}$. The concentration of the total steroids was calculated as $\beta$-sitosterol equivalent, Daksha et al., 2010. The results were average of three determinations.

\section{HPLC analysis of polyphenolics}

Identification of individual polyphenolic compounds in $70 \%$ ethanolic extracts of leaves and pollen grains was performed using HPLC (Goupy et al., 1999). Analysis was performed by reversed phase HPLC/diode array detection (DAD) (Hewlett Packard 1050) using a column Alltima C18, 5mm (150mm x $4.6 \mathrm{~mm}$ id) with a guard column Alltima C18, 5mm (Alltech). Gradient elution of A (acetic acid 2.5\%), B (acetic acid 8\%) and C (acetonitrile) was used. Best separation was at $0 \mathrm{~min}, 5 \% \mathrm{~B}$; at $20 \mathrm{~min}, 10 \% \mathrm{~B}$; at $50 \mathrm{~min}, 30 \% \mathrm{~B}$; at $55 \mathrm{~min}, 50 \% \mathrm{~B}$; at $60 \mathrm{~min}$, $100 \% \mathrm{~B}$; at $100 \mathrm{~min}, 50 \% \mathrm{~B}$ and $50 \% \mathrm{C}$; at $110 \mathrm{~min}, 100 \% \mathrm{C}$ until $120 \mathrm{~min}$. Solvent flow rate was $1 \mathrm{ml} / \mathrm{min}$ and separation was performed at $35^{\circ} \mathrm{C}$.

The volume injected was $10 \mu \mathrm{l}$. Phenolic compounds were assayed by external standard calibration at $280 \mathrm{~nm}$ and expressed in $\mathrm{mg} / \mathrm{g}$ dry matter of equivalent $(+)$-catechin for flavan3-ols, equivalent coumarin for apolar aromatic compounds and equivalent quercetin-3-rutinoside for flavonols.

Identification of the major phenolic components were performed by comparing their retention times to those obtained for the standards (prepared as 50-600 $\mathrm{ug} / \mathrm{ml}$ solutions in methanol). The concentration of individual phenolic component was calculated on the basis of peak area measurements of both standards and samples by adopting the external standard method. Results were the average of triplicate experiments. All standards used were obtained from Sigma. 


\section{HPLC analysis of flavonoids}

The $70 \%$ ethanolic extracts of leaves and pollen grains were subjected to HPLC, adopting the conditions described in (Mattila et al., 2000). Flavonoid analysis was done on Inertsil (GL Sciences, Inc., Japan) using ODS-3 (4.0×150 mm, $3 \mathrm{um})$ column with a C-18 guard column. Temperature of the column oven was set at $35{ }^{\circ} \mathrm{C}$. Gradient elution was employed for flavonoids with a mobile phase consisting of $50 \mathrm{mM} \mathrm{H}_{3} \mathrm{PO}_{4}, \mathrm{pH} 2.5$ (solution A) and acetonitrile (solution $\mathrm{B}$ ) as follows: Isocratic elution $95 \% \mathrm{~A} / 5 \% \mathrm{~B}$, 0-5 min; linear gradient from $95 \% \mathrm{~A} / 5 \% \mathrm{~B}$ to $50 \% \mathrm{~A} / 50 \% \mathrm{~B}, 5-$ $55 \mathrm{~min}$; isocratic elution $50 \% \mathrm{~A} / 50 \% \mathrm{~B}, 55-65 \mathrm{~min}$; linear gradient from $50 \% \mathrm{~A} / 50 \% \mathrm{~B}$ to $95 \% \mathrm{~A} / 5 \% \mathrm{~B}, 65-67 \mathrm{~min}$; post-time $6 \mathrm{~min}$ before next injection. The flow rate of the mobile phase was 0.7 $\mathrm{mL} / \mathrm{min}$, and the injection volumes were $10 u \mathrm{~L}$ of each the standards and sample extracts. Identification of major flavonoids was done by comparing their retention times to those obtained for the standards. Peak areas were used for quantification of both standards and samples using the external standard method. Standard flavonoids calibration curves were made by diluting stock standards in methanol to yield 2-20 $\mathrm{ug} / \mathrm{mL}$. Results were the average of triplicate experiments. Standards of flavonoid aglycones were obtained from different manufacturers and must be in HPLC purity grade.

All standards were prepared as stock solutions at $5 \mathrm{mg} / 50$ $\mathrm{mL}$ in $\mathrm{MeOH}$, except for luteolin and apigenin $(5 \mathrm{mg} / 50 \mathrm{~mL}$ in $\mathrm{DMF} / \mathrm{MeOH}, 1: 6, \mathrm{v} / \mathrm{v})$, and isorhamnetin and rhamnetin $(5 \mathrm{mg} / 50$ $\mathrm{mL}$ in $\mathrm{DMF} / \mathrm{MeOH}, 1: 10$, v/v).

\section{Investigation of lipid content}

$100 \mathrm{~g}$ of each of the air-dried powdered leaves and pollen grains were, separately, extracted with petroleum ether till exhaustion. The extract was evaporated under vacuum to give $0.84 \mathrm{~g}$ and $0.38 \mathrm{~g}$ residue, respectively. The unsaponifiable and saponifiable fractions were obtained from the petroleum ether fraction and the liberated fatty acids were methylated according to Finar, 1973 and Vogel, 1967. GLC conditions for the analysis of unsaponifiable matter (USM) was carried out on a capillary column $(30 \mathrm{~m} \times 0.32 \mathrm{~mm}$ I.D. $\times 0.25 u \mathrm{~m}$ film $)$ and packed with HP-5 (5\% phenyl methyl siloxane), the injected volume was $2 u$. The analysis was carried out at a programmed temperature. Initial temperature was $80^{\circ} \mathrm{C}$ for $5 \mathrm{~min}$. then increased to $280^{\circ} \mathrm{C}$ by the rate of $8^{\circ} \mathrm{C} / \mathrm{min}$., injector and detector (FID) temperatures were $240^{\circ} \mathrm{C}$ and $300^{\circ} \mathrm{C}$, respectively.

Flow rate of nitrogen was $20 \mathrm{ml} / \mathrm{min}$. Fatty acid methyl ester was analysed on the same column used for USM with the same carrier gas but at flow rate of $30 \mathrm{ml} / \mathrm{min}$. The initial temperature was $120^{\circ} \mathrm{C}$ increased to $240^{\circ} \mathrm{C}$ by the rate of $4^{\circ} \mathrm{C} / \mathrm{min}$. the injector and detector (FID) temperatures were $250{ }^{\circ} \mathrm{C}$ and $280{ }^{\circ} \mathrm{C}$, respectively. Identification of compounds was carried out by comparing the retention times of their peaks with those of the available authentic compounds (Sigma Chemical Co. St. Louis, MO, USA) similarly analysed. Quantification was based on peak area measurement using a computing integrator.

\section{Headspace GC/MS analysis of spathe volatiles}

Headspace volatiles analysis using solid phase microextraction (SPME) was adopted from (Farag and Wessjohann, 2012) with slight modification. Frozen spathe sample ( $3 \mathrm{~g}$ ) was cut into small pieces and transferred to SPME screw cap vials $(20 \mathrm{ml})$. Vials were then capped and SPME fiber left to sample then the head space heated above the sample at $50{ }^{\circ} \mathrm{C}$ for $30 \mathrm{~min}$, the fiber withdrawn into the needle and transferred to the injector port of the GC/MS instrument. A system blank containing no plant material was run as a control.

\section{GC/MS parameters}

SPME fibers were desorbed at $210^{\circ} \mathrm{C}$ for $1 \mathrm{~min}$ in the injection port of a shimadzu model GC-17A gas chromatograph interfaced with a shimadzu model QP-5050 mass spectrometer. Volatiles were analysed on a SLB-5 MS column (30 m, $0.25 \mathrm{~mm}$ I.D., $0.25 \mu \mathrm{m}$ film) (Supelco, Oakville, ON, Canada). Injections were made in the splitless mode for 30s. the gas chromatograph was operated under the following conditions: injector $220 \mathrm{C}$, column oven $38^{\circ} \mathrm{C}$ for $3 \mathrm{~min}$, then programmed at a rate of $12^{\circ}$ $\mathrm{C} / \mathrm{min}$ to $180^{\circ} \mathrm{C}$, kept at $180^{\circ} \mathrm{C}$ for $5 \mathrm{~min}$ and finally ramped at a rate of $40^{\circ} \mathrm{C} / \mathrm{min}$. the transfer line and ion source temperatures were adjusted at 230 and $180^{\circ} \mathrm{C}$, respectively. The HP quadrupole mass spectrometer was operated in the electron ionization mode at $70 \mathrm{eV}$. The scan range was set at $\mathrm{m} / \mathrm{z} 40-500$. Volatile components were identified using the procedure described in (Farag and Wessjohann, 2012) and peaks were first deconvoluted using AMDIS software (www.amdis.net) and identified by its retention indices (RI) relative to n- alkanes (C6-C20), mass spectrum matching to NIST, WILEY library database and with authentic standards when available.

\section{RESULTS AND DISCUSSION}

\section{Phytochemical screening}

In the present investigation, preliminary phytochemical screening of leaves and pollens of the plant revealed the presence of flavonoids, saponins, tannins, carbohydrates and/or glycosides, sterols and / or triterpenes.

\section{Proximate analysis}

Pharmacopoeial constants for both organs were determined viz. total moisture content $(6.4 \%$ and $7.7 \%$ in leaves and pollens, respectively), crude fiber $(32.22 \%$ and $39.50 \%$, respectively), total ash (12.1\% and $8.1 \%$ in leaves and pollens, respectively) and acid insoluble ash (4.7 and 7.6\% in leaves and pollens, respectively). These constants can serve as standards for the purity of leaves and pollens as well as for the differentiation from other Phoenix species.

\section{Spectrophotometric determination of different classes of the plant}

The total polyphenolic content were highest in the leaves $(69.9 \mathrm{mg} / \mathrm{g})$ than the pollens $(29.98 \mathrm{mg} / \mathrm{g})$ expressed in GAE per 
gram dry weight; the concentration of total flavonoids calculated as rutin was higher in leaves $(23.86 \mathrm{mg} / \mathrm{g})$ than in pollens $(17.20$ $\mathrm{mg} / \mathrm{g}$ ). Also the total tannins content, were $55.18 \mathrm{mg}$ and $3.31 \mathrm{mg}$ of TAE per gram fresh weight in leaves and pollens, respectively. While the total steroids content, were 2.6 and $12.4 \mathrm{mg} / \mathrm{g}$ per gram dry weight expressed as $\beta$-sitosterol equivalents in leaves and pollens, respectively. The results showed that the leaves were rich in polyphenolics, flavonoids and tannins as compared to pollens while pollens were rich in steroids (Table 1). The total polyphenolic content in 21 Egyptian date fruit varieties of Phoenix dactylifera was previously recorded to vary from 2.33 to $18.97 \mathrm{mg} / \mathrm{g}$ dry weight (Farag et al., 2014). While the phenolic profile of the Algerian type date palm fruit range from 2.49-8.36 $\mathrm{mg} / 100 \mathrm{~g}$ fresh weight GAE (Mansouri et al., 2005). The total phenolic content of seeds of seven different varieties ranges between 1.98 to $4.65 \mathrm{mg} / \mathrm{g}$ GAE (Al-Juhaimi et al., 2012)

Table 1: Quantification of different chemical classes of plant constituents.

\begin{tabular}{lcc}
\hline \multicolumn{1}{c}{ Natural compounds } & Leaves (in $\mathbf{~ m g / g}$ ) & Pollen grains (in $\mathbf{~ m g / g )}$ \\
\hline Polyphenolics & 69.90 & 29.98 \\
Flavonoids & 23.86 & 17.20 \\
Tannins & 55.18 & 3.31 \\
Steroids & 2.60 & 12.40 \\
\hline
\end{tabular}

\section{GLC analysis of lipoidal content}

The percentage of the USM represents $29.98 \%$ and $13.04 \%$ of the total lipids of leaves and pollens, respectively. The GLC analysis of the unsaponifiable fraction resulted in the identification of $83.47 \%$ and $84.68 \%$ of the USM of the leaves and pollens, respectively. The percentage of total hydrocarbons identified was $58.68 \%$ and $47.26 \%$ in the leaves and pollens, respectively. N-docosane (C22) was the major hydrocarbon $(37.54 \%)$ of the leaves while n-tricosane (C23) was the major hydrocarbon in the pollens $(13.43 \%)$. On contrary phytosterols percent was much higher in the pollens $(28.90 \%)$ than in the leaves (4.93\%). Concerning the leaves, $\alpha$-amyrin was the major triterpene $(19.61 \%)$, while $\beta$-sitosterol and campesterol were the main phytosterols $(2.82 \%$ and $1.30 \%$, respectively). In the pollens $\beta$ amyrin was the main triterpene $(5.30 \%)$ while the main phytosterols were campesterol and $\beta$-sitosterol $(10.45 \%$ and $9.96 \%$, respectively) (Table 2 ). The percentage of fatty acids represents $70.02 \%$ and $86.96 \%$ of the total lipids of leaves and pollens, respectively.

Table 2: GLC analysis of the identified USM of the leaves and pollen grains.

\begin{tabular}{llcc}
\hline \multirow{2}{*}{ Authentic } & \multirow{2}{*}{ RRt* } & \multicolumn{2}{c}{ Percent } \\
\cline { 3 - 4 } & & Leaves & Pollen \\
\hline n-Undecane C-11 & 0.254 & 0.79 & 3.74 \\
n-Dodecane C-12 & 0.348 & 2.67 & 0.47 \\
n-Tridecane C-13 & 0.437 & 0.77 & $-\overline{38}$ \\
n- Tetradecane C-14 & 0.493 & 0.90 & 0.82 \\
n- Pentadecane C-15 & 0.592 & 1.23 & 0.73 \\
n- Hexadecane C-16 & 0.639 & 1.42 & 0.96 \\
n- Heptadecane C-17 & 0.711 & 0.23 & 1.08 \\
n- Octadecane C-18 & 0.771 & 1.50 & 3.26 \\
n- Nonadecane C-19 & 0.837 & 3.36 & 1.83 \\
n- Eicosane C-20 & 0.890 & 2.47 & \\
\hline
\end{tabular}

\begin{tabular}{lccc}
\hline n- Henicosane C-21 & 0.948 & -- & 1.88 \\
n- Docosane C-22 & 1 & 37.54 & 1.81 \\
n- Tricosane C-23 & 1.059 & -- & 13.43 \\
n- Tetracosane C-24 & 1.151 & 2.67 & 6.08 \\
n- Pentacosane C-25 & 1.192 & 1.11 & 1.63 \\
n- Hexacosane C-26 & 1.237 & -- & 2.31 \\
n- Heptacosane C-27 & 1.329 & 0.51 & 2.30 \\
n- Octacosane C-28 & 1.395 & 0.55 & -- \\
n- Triacontane C-30 & 1.412 & 0.96 & 4.55 \\
Cholesterol & 1.463 & 0.71 & 3.86 \\
Campsterol & 1.503 & 1.30 & 10.45 \\
Stigmasterol & 1.642 & 0.10 & 4.63 \\
$\beta$-sitosterol & 1.736 & 2.82 & 9.96 \\
$\alpha$-amyrin & 1.845 & 19.61 & 3.22 \\
$\beta$-amyrin & 1.954 & 0.25 & 5.30 \\
\% Total identified compounds & & 83.47 & 84.68 \\
Percentage of total hydrocarbons & & 58.68 & 47.26 \\
Percentage of total phytosterols & & 4.93 & 28.90 \\
Percentage of total triterpenes & & 19.86 & 8.52 \\
\hline * RRt: Relative retention time to n-Docosane C-22 with Rt=20.662 & min. \\
-- : not detected & & &
\end{tabular}

The GLC analysis of fatty acids resulted in the identification of 17 and 19 compounds in leaves and pollens, respectively. Palmitic acid constituted the highest percentage of the saturated fatty acids in the pollens $(27.71 \%)$ and in the leaves $(25.47 \%)$. Concerning the unsaturated fatty acids the $\alpha$-linolenic acid was the major constituent of the leaves (29.12\%), while oleic acid was the major unsaturated fatty acid in the pollens $(20.52 \%)$ (Table 3).

Table 3: GLC analysis of the identified FAME of the leaves and pollen grains.

\begin{tabular}{|c|c|c|c|}
\hline \multirow{2}{*}{ Authentic } & \multirow{2}{*}{ RRt* } & \multicolumn{2}{|c|}{ Percent } \\
\hline & & Leaves & Pollen grains \\
\hline Hexanoic acid C6 (0) & 0.380 & 0.46 & --- \\
\hline Caprylic acid $\mathrm{C}_{8}(0)$ & 0.459 & --- & 0.30 \\
\hline Capric acid $\mathrm{C}_{10}(0)$ & 0.501 & 0.48 & --- \\
\hline Lauric acid $\mathrm{C}_{12}(0)$ & 0.646 & 1.43 & 0.24 \\
\hline Myristic acid $\mathrm{C}_{14}(0)$ & 0.813 & 0.58 & 0.48 \\
\hline Pentadecanoic acid $\mathrm{C}_{15}(0)$ & 0.909 & 0.82 & 0.39 \\
\hline Palmitic acid $\mathrm{C}_{16}(0)$ & 1 & 25.47 & 27.71 \\
\hline Palmitioleic acid $\mathrm{C}_{16}(1)$ & 1.045 & 2.51 & 8.60 \\
\hline Heptadecanoic acid $\mathrm{C}_{17}(0)$ & 1.111 & 1.82 & 0.57 \\
\hline Heptadecenoic acid $\mathrm{C}_{17}(1)$ & 1.143 & 0.50 & 0.86 \\
\hline Heptadecenoic acid $\mathrm{C}_{17}(2)$ & 1.158 & 1.09 & --- \\
\hline Stearic acid $\mathrm{C}_{18}(0)$ & 1.210 & 3.56 & 3.43 \\
\hline Oleic acid $\mathrm{C}_{18}(1)$ & 1.241 & 7.84 & 20.52 \\
\hline Linoleic acid $\mathrm{C}_{18}(2)$ & 1.308 & 19.52 & 18.05 \\
\hline$\alpha$-Linolenic acid $\mathrm{C}_{18}(3)$ & 1.391 & 29.12 & 6.36 \\
\hline$\gamma$-Linolenic acid $\mathrm{C}_{18}(3)$ & 1.483 & 1.58 & --- \\
\hline Arachidic acid $\mathrm{C}_{20}(0)$ & 1.516 & 0.73 & 0.83 \\
\hline Arachidonic acid $\mathrm{C}_{20}(4)$ & 1.576 & 0.26 & 3.71 \\
\hline Ecosapentaenoic acid $\mathrm{C}_{20}(5)$ & 1.664 & --- & 0.63 \\
\hline Behenic acid $\mathrm{C}_{22}(0)$ & 1.753 & --- & 4.52 \\
\hline Erucic acid $\mathrm{C}_{22}(1)$ & 1.833 & --- & 0.28 \\
\hline Tricosanoic acid $\mathrm{C}_{23}(0)$ & 1.915 & --- & 1.51 \\
\hline Lignoceric acid $\mathrm{C}_{24}(0)$ & 2.091 & --- & 0.58 \\
\hline \multicolumn{2}{|c|}{ Percentage of identified fatty acids } & 97.77 & 99.57 \\
\hline \multicolumn{2}{|c|}{ Percentage of unsaturated F.A. } & 62.42 & 59.01 \\
\hline \multicolumn{2}{|l|}{ Percentage of saturated F.A. } & 35.35 & 40.56 \\
\hline
\end{tabular}

Several reports were found concerning the fatty acid profile of seeds and fruits genus Phoenix while little is known 
about the leaves and pollens. Oleic acid was the major fatty acid in most reports of Phoenix dactylifera seeds and fruits (Al-Shahib and Marshall, 2003, Nehdi et al., 2010, Ogungbenle 2011, Akbari et al., 2012, Ben Salah et al., 2012), while linoleic acid was the major in fruits grown in Tunisia (Saafi et al., 2008). In Phoenix theophrasti fruits palmitic acid predominate (Liolios et al., 2009) while in the leaves of Phoenix dactylifera hexadecanoic acid ethyl ester was reported the major (Azmat et al., 2010).

The antioxidant and anti-inflammatory activities of the major identified compounds by GLC; $\alpha$-amyrin, $\beta$-amyrin, $\beta$ sitosterol and polyunsaturated fatty acids; were previously reported by (Zhao et al., 2005, Richard et al., 2008, Melo et al., 2011, Saeidnia et al., 2014). This might be a guide while performing further biological studies.

\section{HPLC analysis of polyphenolics}

The HPLC analysis of the $70 \%$ ethanolic extracts of leaves and pollens separately, revealed quantitative variation in phenolic and flavonoids composition (Tables 4 and 5).

Table 4: HPLC analysis of phenolics in Phoenix canariensis hort ex. Chabaud, leaves and pollen grains.

\begin{tabular}{|c|c|c|c|c|}
\hline \multirow[t]{2}{*}{ No. } & \multirow{2}{*}{$\begin{array}{c}\text { Retention } \\
\text { time } \\
\text { (min) }\end{array}$} & \multirow[t]{2}{*}{$\begin{array}{c}\text { Phenolic } \\
\text { Compounds }\end{array}$} & \multicolumn{2}{|c|}{$\begin{array}{c}\text { Test results of phenolic } \\
\text { compounds (ppm) }\end{array}$} \\
\hline & & & Leaves & Pollen grains \\
\hline 1 & 7.060 & Gallic acid & 295.73 & 62.43 \\
\hline 2 & 7.167 & Pyrogallol & 2537.37 & 1306.95 \\
\hline 3 & 8.333 & 3-OH-Tyrosol & 706.15 & 415.86 \\
\hline 4 & 8.522 & Protocatechuic acid & 1474.01 & 36.40 \\
\hline 5 & 9.249 & Chlorogenic acid & 1232.51 & 572.87 \\
\hline 6 & 9.536 & Catechol & 1682.16 & 362.88 \\
\hline 7 & 9.744 & Catechin & 1513.21 & 546.72 \\
\hline 8 & 10.358 & Caffeic acid & 484.00 & 238.19 \\
\hline 9 & 10.494 & Vanillic acid & 876.02 & 320.56 \\
\hline 10 & 11.808 & Para-coumaric acid & 430.61 & 86.31 \\
\hline 11 & 11.977 & Ferulic acid & 505.68 & 547.86 \\
\hline 12 & 12.293 & Iso-ferulic acid & 159.12 & 31.29 \\
\hline 13 & 12.846 & Rosmarinic acid & 2198.51 & 448.70 \\
\hline 14 & 12.849 & Reversetrol & 564.14 & 131.48 \\
\hline 15 & 13.067 & Ellagic acid & 220.44 & 266.82 \\
\hline 16 & 13.146 & Ethyl vanillic acid & 35008.54 & 11624.22 \\
\hline 17 & 13.553 & $\begin{array}{l}\text { Alpha-coumaric } \\
\text { acid }\end{array}$ & 5486.41 & 1815.54 \\
\hline 18 & 14.456 & Salycilic acid & 3891.13 & 822.15 \\
\hline
\end{tabular}

Table 5: HPLC analysis of flavonoids in Phoenix canariensis hort ex. Chabaud, leaves and pollen grains.

\begin{tabular}{ccccc}
\hline No & $\begin{array}{c}\text { Retention } \\
\text { time }\end{array}$ & Flavonoids & \multicolumn{2}{c}{ Concentration $(\mathbf{p p m})$} \\
\cline { 4 - 5 } & & & Leaves & Pollen grains \\
\hline 1 & 12.233 & Luteolin & 622.27 & 190.94 \\
2 & 12.287 & Naringin & 2376.32 & 556.56 \\
3 & 12.441 & Rutin & 3800.79 & 292.48 \\
4 & 12.571 & Hesperidin & 10295.90 & 1062.40 \\
5 & 13.467 & Quercetrin & 939.21 & 577.10 \\
6 & 13.905 & Isorhamnetin & 17785.44 & 4349.10 \\
7 & 14.978 & Quercetin & 1050.32 & 140.14 \\
8 & 15.631 & Hesperetin & 1213.06 & 138.92 \\
9 & 16.257 & Kampferol & 442.84 & 167.01 \\
10 & 16.551 & Apigenin & 157.26 & 790.55 \\
\hline
\end{tabular}

Eighteen different phenolic compounds were identified, where ethyl vanillic acid was the major phenolic acid identified in both organs, its antioxidant (Tai et al., 2011) and antiinflammatory (Jung et al., 2010) activities were previously reported. Concerning the flavonoids, ten flavonoids were identified in both organs, where isorhamnetin predominates at a concentration of $17785.44 \mathrm{ppm}$ and $4349.10 \mathrm{ppm}$ in leaves and pollens, respectively. Isorhamnetin was reported to exhibit antiinflammatory (Seo et al., 2014), anti-obesity (Lee et al., 2009), anti-oxidant (Pengfei et al., 2009), and antitumor (Teng et al., 2006) activities. The metabolomics fingerprints of 21 Egyptian date fruit varieties of Phoenix dactylifera were previously studied by Farag et al., 2014. Luteolin and apigenin glycosides predominates the flavones identified while quercetin conjugates were the principle flavonols. Caffeoyl shikimic acid was the main hydroxylcinnamic conjugate.

\section{Headspace GC/MS analysis of spathe volatiles.}

Headspace volatile analysis combined with GC/MS was utilized for detection of spathe volatiles (Table 6). The percentage of total hydrocarbons, monoterpenes and sesquiterpene hydrocarbons as well as the percentage of total oxygenated compounds and oxygenated monoterpenes were calculated (Table 7).

Table 6: Identified components in spathe essential oil

\begin{tabular}{|c|c|c|c|c|c|}
\hline $\begin{array}{c}\text { Peak } \\
\text { no. }\end{array}$ & Identified compounds & RRI & $\begin{array}{l}\text { Base } \\
\text { peak }\end{array}$ & M+ & Conc. \%* \\
\hline 1 & n-Hexanal & 802.1 & 44 & 72 & 0.5 \\
\hline 2 & o-Xylene & 870.2 & 91 & 106 & 0.92 \\
\hline 3 & Styrene & 885 & 104 & 107 & 1.37 \\
\hline 4 & Heptanal & 898 & 44 & 96 & 1.61 \\
\hline 5 & Benzaldehyde & 967 & 77 & 105 & 0.82 \\
\hline 6 & n-heptanol & 968.9 & 41 & 80 & 0.64 \\
\hline 7 & 2-Pentylfuran & 991 & 81 & 138 & 3.07 \\
\hline 8 & n-octanal & 1005 & 41 & 100 & 0.97 \\
\hline 9 & 3-carene & 1013 & 93 & 136 & 1.87 \\
\hline 10 & m-Cymene & 1029 & 119 & 134 & 1.21 \\
\hline 11 & 2-Ethylhexanol & 1033 & 57 & 98 & 4.77 \\
\hline 12 & D-limonene & 1034 & 68 & 136 & 0.49 \\
\hline 13 & Benzene acetaldehyde & 1050 & 91 & 120 & 0.96 \\
\hline 14 & 2-octenal & 1063 & 41 & 93 & 1.03 \\
\hline 15 & 1-octanol & 1075 & 41 & 95 & 0.75 \\
\hline 16 & p-1,3,8-Menthatriene & 1090 & 119 & 134 & 0.32 \\
\hline 17 & Linalool & 1102 & 91 & 134 & 0.41 \\
\hline 18 & n-nonanal & 1095.6 & 57 & 124 & 3.44 \\
\hline 19 & $(E, E)-2,6$-Nonadienal & 1158 & 41 & 79 & 0.41 \\
\hline 20 & 2-nonenal & 1165 & 43 & 148 & 0.61 \\
\hline 21 & Caprylic acid & 1171 & 61 & 101 & 0.44 \\
\hline 22 & n-nonanol & 1175 & 56 & 98 & 0.42 \\
\hline 23 & 4-terpineol & 1192 & 71 & 136 & 0.43 \\
\hline 24 & Estragole & 1205 & 59 & 148 & 0.18 \\
\hline 25 & Decanal & 1209 & 43 & 112 & 0.88 \\
\hline 26 & $\beta$-cyclocitral & 1232 & 41 & 152 & 0.57 \\
\hline 27 & Thymoquinone & 1258.8 & 43 & 194 & 0.29 \\
\hline 28 & Nonanoic acid & 1267 & 60 & 129 & 0.42 \\
\hline 29 & $\begin{array}{l}\text { (3E)-8-Methyl-3,7- } \\
\text { nonadien-2-one }\end{array}$ & 1274 & 69 & 109 & 0.33 \\
\hline 30 & Tridecane & 1300 & 57 & 99 & 0.25 \\
\hline 31 & 1-methyl naphthalene & 1314 & 115 & 142 & 0.34 \\
\hline 32 & $\begin{array}{l}\text { Isolongifolene, } 9,10- \\
\text { dehydro- }\end{array}$ & 1338 & 131 & 202 & 0.52 \\
\hline 33 & $\delta$-EIemene & 1345 & 81 & 204 & 0.3 \\
\hline 34 & $\alpha$-cubebene & 1360 & 161 & 204 & 2.87 \\
\hline 35 & $\begin{array}{l}\text { 8-methylene- } \\
\text { tricyclo[3.2.1.0(2,4)]octane }\end{array}$ & 1379 & 91 & 119 & 0.5 \\
\hline
\end{tabular}




\begin{tabular}{llcccc}
\hline 36 & Longifolene-I2 & 1389 & 94 & 204 & 0.3 \\
37 & $\alpha$-copaene & 1393 & 119 & 204 & 18.72 \\
38 & $\beta$-cubebene & 1402 & 161 & 204 & 2.51 \\
39 & Unknown & 1410 & 119 & 202 & 9.23 \\
40 & $\alpha$-Gurjunene & 1425 & 118 & 204 & 0.37 \\
41 & (E)- $\alpha$-Ionone & 1433 & 121 & 202 & 0.11 \\
42 & Caryophyllene & 1439 & 41 & 189 & 2.2 \\
43 & Unidentified sesquiterpene & 1448 & 161 & 189 & 0.65 \\
44 & Aromadendrene & 1453 & 119 & 202 & 1.4 \\
45 & Isocaryophyllene & 1458 & 41 & 135 & 0.43 \\
46 & $\alpha$-humulene & 1476 & 133 & 136 & 0.94 \\
47 & Allo-aromadendrene & 1481 & 41 & 189 & 1.82 \\
48 & $\gamma$-Muurolene & 1491 & 41 & 159 & 1.43 \\
49 & Germacrene D & 1501 & 161 & 204 & 2.97 \\
50 & Viridiflorene & 1510 & 107 & 204 & 0.44 \\
51 & Elixene & 1515 & 121 & 189 & 1.47 \\
52 & $\delta$-cadinene & 1518.9 & 161 & 204 & 1.95 \\
53 & Calamenene & 1536 & 159 & 159 & 0.46 \\
54 & Naphthalene, 1,2,3,4,4a,7- & 1547 & 119 & 204 & 0.41 \\
\multicolumn{5}{c}{} \\
hexahydro-1,6-dimethyl-4- \\
(1-methylethyl)-
\end{tabular}

Table 7: The calculated percentage of different classes of the spathe oil compounds.

\begin{tabular}{lc}
\hline Oil constituents & Percentage \\
\hline Identified components & 72.84 \\
Unknown compounds & 27.16 \\
Monoterpene hydrocarbons & 3.89 \\
Sesquiterpenes hydrocarbons & 41.51 \\
Total hydrocarbons & 48.78 \\
Oxygenated monoterpenes & 2.03 \\
Total oxygenated compounds & 23.73 \\
Total monoterpenes & 5.92 \\
Total sesquiterpenes & 41.51 \\
Major constituent: Copaene<alpha> & 18.72 \\
\hline
\end{tabular}

A total of 52 compounds were detected. Sesquiterpene hydrocarbons constituted the most dominant class with $41.51 \%$ where $\alpha$-copaene predominates (18.72\%). Concerning oxygenated compounds, total oxygenated compounds were $23.73 \%$, where 2ethylhexanol $(4.77 \%)$ was the major oxygenated compound, while oxygenated monoterpenes were found to be $2.03 \%$,

In conclusion, the results provide the first study on volatiles of spathe from the plant while several reports were found concerning the spathe of the well-known species Phoenix dactylifera (Hamedi et al., 2013, Jahromi et al., 2014).

\section{CONCLUSION}

This study is the first report that shed light on leaves and pollens of Phoenix canariensis Hort. ex Chabau cultivated in Egypt, in addition to its spathe volatile analysis. The leaves are rich in polyphenolics, flavonoids and tannins as compared to pollens while pollens are rich in steroids. The main components identified by GLC and HPLC might suggest their incorporation in antioxidant and anti-inflammatory preparations. Further studies are required to evaluate the plant biological activities and to isolate the bioactive compounds.

\section{Financial support and sponsorship: Nil.}

Conflict of Interests: There are no conflicts of interest.

\section{REFERENCES}

AOAC, 2000. Official Methods of Analysis of the Association of Official Analytical Chemist. $14^{\text {th }}$ ed., Washington D.C.

Adawy SS, Hussein EHA, El-Khishin DA, Saker MM, El-Itriby HA. Genetic variability studies and molecular fingerprinting of some Egyptian date palm (Phoenix dactylifera L.) cultivars. II-RAPD and ISSR Profiling. Arab. J. Biotech, 2002; 5, 225-236.

Akbari M, Razavizadeh R, Mohebbi GH, Barmak A. Oil Characteristics and Fatty Acid Profile of Seeds from Three Varieties of Date Palm Phoenix dactylifera Cultivars in Bushehr-Iran., African Journal of Biotechnology, 2012; 11, 12088-12093.

Al-Juhaimi F, Ghafoor K, Ozcan, M M. Physical and Chemical Properties, Antioxidant Activity, Total Phenol and Mineral Profile of Seeds of Seven Different Date Fruit Phoenix dactylifera Linn.,Varieties. International Journal of Food Sciences and Nutrition, 2012; 63, 8489.

Al-Shahib W, Marshall R. Fatty Acid Content of The Seeds from Fourteen Varieties of Date Palm Phoenix dactylifera Linn. International Journal of Food Science and Technology, 2003; 38, 709-712.

Al-Zoreky NS, Al-Taher AY. Antibacterial activity of spathe from Phoenix dactylifera L. against some food-borne pathogens. Industrial crops and products, 2015; 65, 241-246.

Asami A, Hirai Y, Shoji J. Studies on the Constituents of Palmae Plants, Steroid Saponina and Flavonoids of Leaves of Phoenix canariensis hort. ex Chabaud, P. humilis Royle var. hanceana Becc., $P$. dactylifera L., and Licuala spinosa Wurmb, Chemical and Pharmaceutical Bulletin, 1991; 39, 2053-2056.

Azmat S, Ifzal R, Rasheed M, Mohammad FV, Ahmad VU. GC-MS Analysis of n-hexane Extract from Seeds and Leaves of Phoenix dactylifera L. Journal of the Chemical Society of Pakistan, 2010; 32, 672676.

Ben Salah S, Emna B, Flamini G, El Arem A, Issaoui M, Dabbou S, BenYahia L, Ferchichi A, Hammami M, Achour L. Compositional Characteristics and Aromatic Profile of Date Palm Seeds from Seven Varieties Gown in Tunisia, International Journal of Food Science and Technology, 2012; 47, 1903-1908.

Claus EP, Tyler V. Pharmacognosy $5^{\text {th }}$ Ed., Lea Febiger, Philadelphia, 1967; 271-273.

Daksha A, Jaywant P, Bhagyashree C, Subodh P. Estimation of sterols content in edible oil and ghee samples. Electronic Journal of Environment, Agriculture and Food Chemistry, 2010; 9, 1593-1597.

Earp CF, Akingbala JO, Ring SH, Rooney LW. Evaluation of several methods to determine tannins in sorghums with varying kernel characteristics. J. Cereal Chemistry, 1981; 58, 234-238.

Elgindi MR, Singab AN, El-Taher EMM, Kassem MES. A comprehensive review of Phoenix (Arecaceae). Research journal of pharmaceutical, biological and chemical sciences, 2015; 6, 966-974.

Evans WC, 2002. Trease and Evans Pharmacognosy. $15^{\text {th }}$ Ed., 50, WB Saunders Elsevier Company Ltd.

Farag MA, Wessjohann LA. Volatiles Profiling in Medicinal Licorice Roots Using Steam Distillation and Solid-Phase Microextraction (SPME) Coupled to Chemometrics. Journal of Food Science, 2012; 77, 1179-1184.

Farag MA, Mohsen M, Heinke R, Wessjohann LA. Metabolomic fingerprints of 21 date palm fruit varieties from Egypt using UPLC/PDA/ESI-qTOF-MS and GC-MS analyzed by chemometrics. Journal of food research international, 2014; 64, 218-226.

Fieser LF, Fieser M. 1959. Steroids. Reinhold Publishing Co., New York, 727-743. 
Finar, IL. 1973. Organic chemistry, sixth ed., Longman group Ltd., England.

Garcia B, Alberto M, Eliseo S, Amparo T. Triterpenes, Waxes and Tricin in Phoenix canariensis hort ex. Cabaud, Journal of Natural Products, 1981; 44, 111-113.

Geissman, TA. The Chemistry of Flavonoid Compounds, Macmillam Company, New York, 1962; 318-320.

Gilman E, Watson D. 2006. Phoenix canariensis Canary Island Date Palm.Bulletin ENH-598. Institute of Food and Agricultural Sciences, University of Florida.

Goupy P, Hugues M, Boivin P, Amiot M. Antioxidant composition and activity of barley (Hordeum vulgare) and malt extracts and of isolated phenolic compounds. Journal Sci. Food Agriculture, 1999; $79,1625-1634$

Hamedi A, Mohagheghzadeh A, Rivaz S. Preliminary Pharmacognosy Evaluation and Volatile Constituent Analysis of Spathe of Phoenix dactylifera L., Pharmacognosy Journal, 2013; 5, 83-86.

Hammami S, Jarraya H, Ben Salem S, Hamdi B, Ben Salah A, Devi P, Nefzi A, Mighri Z. Isolation and Structure Elucidation of Novel Alkaloid from Phoenix canariensis hort ex. Cabaud. Palm Tree, Journal de la Societe Chimique de Tunisie, 2010; 12: 105-108.

Jahromi MF, Moein M R, Etemadfard H, Johromi Z. Variation of Spathe Essential Oil Composition of Ten Iranian Date Varieties (Phoenix dactylifera L.). International Journal of Plant, Animal and Environmental Sciences, 2014; 4: 51-56.

Johnson DV. 1998. Tropical palms, FAO Forestry report, nonwood Forests Products No.10. FAO, Rome.

Jung HJ, Song YS, Kim K, Lim CJ, Park EH. Assessment of the anti-angiogenic, anti-inflammatory and antinociceptive properties of ethyl vanillin. Archives of pharmacal research, 2010; 33, 309-316.

Kchaou, W., Abbès, F., Blecker, C., Attia, H.,Besbes, S. Effects of extraction solvents on phenolic contents and antioxidant activities of Tunisian date varieties (Phoenix dactylifera L.). Industrial crops and products, 2013; 45: 262-269.

Krueger R. 2001. Date palm germplasm overview and utilization in the USA. Proceedings international conference on date palms.

Lee J, Jung E, Lee J, Kim S, Huh S, Kim Y, Kim Y, Byun SY, Kim YS, Park D. Isorhamnetin Represses Adipogenesis in 3T3-L1 Cells. Obesity, 2009; 17, 226-232.

Liolios CC, Sotiroudis GT, Chinou I. Fatty Acids, Sterols, Phenols and Antioxidant Activity of Phoenix theophrasti Fruits, Growing in Crete, Greece, Plant Foods for Human Nutrition, 2009; 64, 52-61.

Mansouri A, Embarek G, Kokkalou E, Kefalas P. Phenolic profile and antioxidant activity of the Algerian ripe date palm fruit (Phoenix dactylifera L.), Food Chemistry, 2005; 89,411-420.

Mattila P, Astola J, Kumpulainen J. Determination of flavonoids in plant material by HPLC with Diode-Array and Electro-Array Detections. Journal of Agri. Food Chem., 2000; 48, 5834-5841.

Melo CM, Morais TC, Tomé AR, Brito GAC, Chaves MH, Rao VS, Santos FA. Anti-inflammatory effect of $\alpha, \beta$-amyrin, a triterpene from Protium heptaphyllum, on cerulein-induced acute pancreatitis in mice. Inflammation Research, 2011; 60, 673-681.

Mohtasheem M, Waseemuddin A, Iqbal A, Husan B, Ahmad VU, Ali MS. Biological activity and phytochemistry of Phoenixspecies. Hamdard Medicus, 2005;48.

Nehdi IA, Omri S, Khalil MI, Al-Resayes SI. Characteristics and Chemical Composition of Date Palm, Phoenix canariensis hort. ex Chabaud, Seed and Seed Oil. Industrial Corp and Products, 2010; 32,360365.

Nehdi IA, Zarrouk H, Al-Resayes SI. Changes in Chemical Composition of Phoenix canariensis hort. ex Chabaud Palm Seed Oil During the Ripening Process. Scientia Horticulturae, 2011; 129, 724-729.

Ogungbenle HN. Chemical and Fatty Acid Composition of Date Palm Fruit Phoenix dactylifera Linn., Flour. Bangladesh Journal of Scientific and Industrial Research, 2011; 46, 255-258.

Peach K, Tracey MV. Modern Methoden Der Pflazen Analyse. Tgottingen, Heidelberg, 1955; 3, 450.
Pengfei L, Tiansheng D, Xianglin , Jianguo W. Antioxidant properties of isolated isorhamnetin from the sea buckthorn marc. Plant foods for human nutrition, 2009; 64, 141-145.

Pujari RR, Vyawahare NS,Thakurdesai PA. Neuroprotective and antioxidant role of Phoenix dactylifera in permanent bilateral common carotid occlusion in rats. Journal of Acute Disease, 2014; 3, 104-114.

Rahmani AH, Aly SM, Ali H, Babiker AY, Srikar S. Therapeutic effects of date fruits (Phoenix dactylifera) in the prevention of diseases via modulation of anti-inflammatory, anti-oxidant and antitumour activity. International Journal of Clinical and Experimental Medicine, 2014; 7.

Richard D, Kefi K, Barbe U, Bausero P, Visioli F. Polyunsaturated fatty acids as antioxidants. Pharmacological research, 2008; 57, 451-455.

Saafi E, Trigui M, Thabet R, Hamammi M, Achour L. Common Date Palm in Tunisia: Chemical Composition of Pulp and Pits, International Journal of Science and Technology, 2008; 43, 2033-2037.

Saeidnia S, Manayi A, Gohari AR, Abdollahi M. The story of beta-sitosterol-a review. European Journal of Medicinal Plants, 2014; 4, 590 .

Seo K, Yang JH, Kim SC, Ku SK, Ki SH, Shin SM. The antioxidant effects of isorhamnetin contribute to inhibit COX-2 expression in response to inflammation: a potential role of HO-1. Inflammation 2014; $37,712-722$

Singab AN, El-Taher EMM, Elgindi MR, Kassem MES. Phoenix roebelenii O'Brien DNA profiling, bioactive constituents, antioxidant and hepatoprotective activities. Asian Pacific Journal of Tropical Disease, 2015; 5, 552-558.

Singleton VL, Orthofer R, Lamuela RRM. Analysis of Total Phenols and Other Oxidation Substrates and Antioxidants by Means of Folin-Ciocalteu Reagent. Methods Enzymol., 1999; 299,152-178.

Tai A, Sawano T, Yazama F. Antioxidant Properties of Ethyl Vanillin in vitro and in vivo. Bioscience, biotechnology, and biochemistry, $2011 ; 75,2346-2350$.

Teng BS, Lu YH, Wang ZT, Tao XY, Wei DZ. In vitro antitumor activity of isorhamnetin isolated from Hippophae rhamnoides L. against BEL-7402 cells. Pharmacological research, 2006; 54, 186-194.

Tiwari P, Kumar B, Kaur M, Kaur G, Kaur H. Phytochemical screening and extraction: a review. Internationale pharmaceutica sciencia, $2011 ; 1,98-106$.

Vogel Al. 1967. A Text book of practical organic chemistry. Longmans and green Co. Ltd., London.

Wagner H, Baldt S, Zganski EM, 1983. Droger Analyse. Springer Verlag, Berlin, 6.

Zaid A, Arias-Jimenez EJ. 2002. Date Palm Cultivation. FAO Plant production and protection paper 156, Rev.1. FAO, Rome.

Zhao G, Etherton TD, Martin KR, Heuvel JPV, Gillies PJ, West SG, Kris-Etherton PM. Anti-inflammatory effects of polyunsaturated fatty acids in THP-1 cells. Biochemical and biophysical research communications, 2005; 336, 909-917.

Zohary D, Hopf M. 2000. Domestication of plants in the old world: the origin and spread of cultivated plants in West Asia, Europe, the Nile Valley Oxford University Press, Oxon, UK.

How to cite this article:

Hifnawy MS, Mahrous AMK, Ashour RMS. Phytochemical investigation of Phoenix canariensis Hort. ex Chabaud leaves and pollen grains. J App Pharm Sci, 2016; 6 (12): 103-109. 